\title{
CHANGING ACCESSIBILITY OF POLISH AIRPORTS ON THE COURSE OF DEMOGRAPHIC AND ECONOMIC DEMAND*
}

\author{
TOMASZ KOMORNICKI and PRZEMYSŁAW ŚLESZYŃSKI \\ Institute of Geography and Spatial Organization Polish Academy of Sciences, \\ Twarda 51/55, 00-818 Warsaw, Poland \\ E-mails: t.komorn@twarda.pan.pl,.psleszyn@twarda.pan.pl
}

\begin{abstract}
The demand for air services is analysed using a methodology based on catchment area designation by driving-time zones (time-wise accessibility by individual car transport). Calculated for the zones in question were: absolute and relative demographic demand, absolute economic demand (number of businesses within a particular catchment area) and relative economic demand. The study suggests four variants where demand is concerned, according to existing and planned locations, as of 2008 and 2015.
\end{abstract}

Key words: airports, air travel, demand forecasting, demographic and economic demand, catchment area, market area, spatial accessibility, Poland.

\section{INTRODUCTION}

The civilisational and economic transformations taking place with increasing intensity have specific effects on forms and means of transport and communication. In recent years the world in general, and Poland and other countries of Central Europe in particular, have witnessed an exceptionally dynamic development of air transport. This has necessitated a reformulating of some objectives of regional policies, and hence also the introduction of corrections into various kinds of development strategies, (spatial) development plans, etc. In the new member

The article is an expanded and modified version of the study, published by the authors in the 16 th volume of Prace Komisji Geografii Komunikacji PTG [Works of the Commission of Communicational Geography of the Polish Geographical Society]; Komornicki and Sleszyński 2009a). states of the European Union, this process has coincided with a possibility to obtain support for investment projects related to air transport from the Structural Funds. At the same time, increasing challenges as regards economic competitiveness plus expectations of potential customers ensure that more effective location policies need to be pursued. Contemporary decision makers face a question as to how to ensure such properties of the transport system as will make their respective locations yield the greatest possible social and economic benefits. This reflects the increasing significance in both scientific research and planning documents, on both European and national levels, of spatial accessibility, understood in a comprehensive manner in the multimodal (inter-branch) dimension. In the context of airborne transport this means the already common acceptance of the fact that airport planning 
exceeds the terminals and runways themselves, having become a regional problem, resolved precisely by means of the forecasting of accessibility (Garriga 2006).

In the scientific and pragmatic discussion of the locations of airports, emphasis is very much placed on demand exerted by inhabitants and businesses. This is also why the economic analyses accompanying business plans for investment projects concerning airport infrastructure have calculated indicators relating to potential populations and numbers of businesses to whom the service is to be provided.

Such premises are certainly correct, but they in practice encounter three groups of essential methodological and technical difficulties, influencing the final effect of analyses and requiring estimation. The first of these is connected with the degree of liberalisation or functioning of freemarket principles in air transport, and with the latter's position with respect to other branches of transport (Graham 1998). This is linked with the functioning of air transport in conditions of competition, as well as its substitution by other means of transport, especially in the network settings to which air transport is increasingly subordinated (Encaoua et al. 1996). Given the weak development of modern road and railway networks in Poland, as well as the quite recent monopoly in air transport, this context assumes great significance. On the other hand, certain authors have argued recently that the prevalence of air transport over railways in the CEECs is not at all obvious, even though the quality of service of the former is in principle higher (Janic 1997). For instance, recent studies show that the bringing into service of high-speed railways may result in a drop in domestic passenger air traffic by even more than 50\% (Park and Ha 2006, Concepción et al. 2007).

The second category of conditions is closely connected with the heterogeneity of societies and businesses, non-homogeneous from the point of view of demand generation, since not all categories of inhabitants are interested in air transport services to the same degree (Bieger et al. 2007). This mainly reflects educational level and the nature of professional activity engaged in, as not all occupations give similar rise to demand for air services. Thus the level of employment in services is of much greater significance to the development of the air transport market than employment in farming, such a state of affairs naturally resulting in an emphasis on metropolitan areas (Pels et al. 2000). Another, equally significant factor is associated with material status and the demand for tourist services. Yet another element particularly important in the case of Poland is constituted by oscillating job-related $\mathrm{mi}-$ grations to other countries of the European Union. It was specifically the 'official' opening up of the job markets in several Western European countries, notably the United Kingdom, that has been a major factor underpinning the intensive development of air transport services in Poland during the last decade.

The third category of methodological difficulty involves the a mbiguities of spatial accessibility, and is related to the uneven distribution of ground transport infrastructure, which determines the actual accessibility of airports. As a rule, the actual pattern displayed by catchment areas is not concentric, as is frequently shown on simplified schemes intended to illustrate the demographic hinterland for air transport facilities. The fundamental problem with the determination of demand for air transport is in fact associated with the correct defining of the reach of a given potential investment project. Such analyses ought to assume that a potential passenger is driven by economic rationality and selects the airport reachable in the shortest time or in the cheapest way.

Summing up, the large number of variables influencing the level of demand for air transport is now making forecasting of its development very difficult. This is yet further compounded by the fact that travelling by air also has a significant psychological aspect, as was made perfectly clear through the so-called 'September 11th effect' (Blake 
and Sinclair 2003, Lai and Lu 2005). Adradni et al. (2005) even go as far as to suggest that the economic-statistical methods used to date are no longer of use, with the forecasting of air services necessitating a resort to nonlinear analyses and chaos theory. Nevertheless, as under market conditions it is demand which remains the leading prerequisite for the development of virtually any kind of business activity (not only in services), detailed studies in this domain are definitely still of fundamental importance.

\section{METHODOLOGICAL PREREQUISITES}

Even when the aforementioned limitations and difficulties are taken into account, one of the ways to define and calculate demand for air transport remains to construct catchment areas for particular airports on the basis of transport-wise accessibility. The approach associated with the use of market areas has gained common application in studies on the location of economic activities since the time the gravitational action of services located at a definite point was established (Reilly 1931, Huff 1964). This approach is also applied, in a somewhat different perspective, in analyses of the development of air transport (Pantazis and Liefner 2006).

The determination of temporal accessibility requires some additional simplifications linked with the mode of transport and technical or actual velocity on roads, as limited by various factors first and foremost reflecting technical parameters and traffic intensity, but also population density and relief differentiation. The work described here has thus sought to determine the present and forecasted market catchment areas for Poland's existing and planned airports, and then to estimate the level of demographic and economic demand the said areas generate.

Demand for air services can be defined in relation to reach as absolute (total) or zonal (partial). While the former applies where competitive limitations are absent and the airport under consideration operates in isolation, the latter accounts for the existence of competing airports, and demand is divided as appropriate between all analysed facilities. The division may be performed in different ways, but the analysis presented here assumes that the boundary between the catchments of two, or more, airports, is nominally formed by places of equal temporal distance.

The work described in this report has thus adopted the second perspective, which concedes the existence of many airports. Two time-instants are considered, i.e. the present day and the year 2015, by which time an end will have been put to the infrastructural projects envisaged in programmes cofinanced by the EU that have the most major influence on time-wise accessibility of airports nationally. Accessibility has been analysed by reference to time of travel in a passenger car, in view of the near-universality of car ownership and obvious domination of road transport in the modal structure of transport. The four variants for the development of demand considered in the analysis were:

1) Variant A: the current situation-year 2009, the existing 11 facilities (Warsaw-Okęcie, Szczecin-Goleniów, Gdańsk-Rębiechowo, Poznań-Ławica, Łódź-Lublinek, Zielona Góra-Babimost, Bydgoszcz-Szrederowo, Wrocław-Strachowice, Kraków-Balice, Katowice-Pyrzów, Rzeszów-Jasionka);

2) Variant B: situation as of the year 2015 , but not accounting for any new facilities;

3) Variant C: situation as of the year 2015, accounting for the establishment of four additional airports that will almost certainly by then be open, or at least close to achieving the finalization of projects concerning them, i.e. Warsaw-Modlin, Bialystok-Krywlany, Lublin-Swidnik, and also Olsztyn-Szymany (ã facility álreảdy in existence, but not hosting regular flights);

4) Variant D: situation as of the year $2013 / 15$, accounting not only for the (above) 'certain' facilities, but also five others currently at different stages of project advancement (Kielce-Obice, Rádom-Sảków, 
Sochaczew, Koszalin/Kołobrzeg-Zegrze Pomorskie, Opole-Kamień Śląski).

For all these variants the indicators calculated were:

1) $P_{D(b)}$, absolute demographic demand, i.e. number of population within the given market catchment area;

2) $\mathrm{P}_{\mathrm{E}(\boldsymbol{b})}$, absolute economic demandnumber of enterprises (registered economic entities) located within the given market catchment area;

3) $P_{D(w)}$, demographic demand weighted by four variables: the population of mobility working age (18-39 years), number of employment persons in services sector, number of foreign tourists, number of population with tertiary education. All variables were equal weight (25\%) and all as related to the country as a whole (Poland $=100 \%$ );

4) $P_{E(w)}$, economic demand, weighted by five variables: the share in GDP, number of enterprises (registered economic entities) in the higher-order services sector, number of companies with foreign capital, number of commercial companies, and again number of foreign tourists. All variables were of equal weight (20\%), again as set against the country as a whole (Poland $=100 \%$ ).

The calculations made use of the most recent available data from the Central Statistical Office (GUS), i.e. those for 2007 or exceptionally 2002 (educational level of population according to the last national census). Calculations for 2015 are unfortunately based on a serious simplification that accounts for neither demographic growth or decline, nor for changes in concentrations in particular categories of inhabitant or business. In other words, the calculations show the effects of extending the airport network and road infrastructure in regard to a socioeconomic structure remaining static. Considering the known polarisation processes entailing increasing shares for the Warsaw metropolitan area and other agglomerations of the 'Big Five' (Kraków, Poznań, the Tri-City and Wroclaw) where the majority of the basic social and economic indicators are concerned (Węclawowicz et al., 2006), we can expect underestimá- tions of the order of $3 \%$ for these centres and the airports located close to them, when it comes to absolute and percentage values for demand.

The determined means of deciding upon market catchment areas is a potential one, assuming that it is possible to establish any domestic or international flight connection from any functioning airport, and hence further assuming that passengers do not choose airports from the point of view of their flight offer, but only in terms of the facility with (time during) which they can be reached from a person's place of residence. This is, of course, a significant simplification, especially for the shorter distances over which competition with other means of transport may be experienced. Equally, the assumption is much more justified when it comes to the more distant (especially intercontinental) destinations to which travel is based around hubs.

\section{AIR TRAFFIC IN POLAND AFTER 1990}

Despite economic development and a significant increase in the intensity of various kinds of international interaction post 1990, the demand for air transport in Poland remained relatively weak in both Warsaw and Poland as a whole until 1995. The basic causes of this state of affairs were:

- the income level of the Polish population and attendant successful competition for international passenger carriage engaged in by the cheaper coach lines (at a time when air fares remained at relatively high);

- the polycentric spatial structure of the country (Espon 1.1.1 Final report, 2005);

- geographical distance to some of the important destinations (especially in Germany);

- competition from the airports in Berlin and Copenhagen;

- a high level of market regulation;

- a perception that air transport was expensive that had developed in earlier periods. 
Post-1990, Polish air transport passed through two waves of rapid increases in transport intensity. The first of these-occurring in the years 1996-2000-was associated with rapid economic development (and hence numerous business trips), as well as an increase in numbers of chartered tourist flights (mainly oriented at the Mediterranean). The second wave was in turn initiated by Poland's (2004) accession to the European Union, with the basic agent here being the appearance of low-cost flight operators. The gradual change of fare policy pursued by LOT Polish Airlines also contributed to increased traffic on domestic flights. In conjunction with deregulation activity, these two waves brought about a systematic decentralisation of air traffic. Hence, the years after 2004 brought an abrupt increase in numbers of passengers being serviced at KrakowBalice and Katowice-Pyrzowice Airports, for example, these also being the locations at which the roles won for themselves by "cheap airlines" were greatest, accounting as they did for 46 and $70 \%$ shares respectively (Czyczula et al. 2005) ${ }^{1}$.

Notwithstanding the changes described, Poland continues to see rather small per capita numbers of air passengers serviced. When we set the incidence of air travel per capita against GDP, we note that Spain is characterised by the highest intensity. Equally, the group of European countries with low values for this indicator includes both France (this partly justified by the well-developed network of high-speed railways) and Poland (Czyczula et al. 2005). While Europe's largest airports (London-Heathrow, Frankfurt a/M., Paris-Charles de Gaulle and Amsterdam-Schiphol) service more than 40 million pâssengers a year, the totâl traffic at âll Polish airports in 2008 was of just 18 million passengers. These data indicate a potentially great capacity for further development to take place on the Polish market.

1 More about airports development in the geographic aspect of view, see also: Kitowski 1999, Kopec 2004, Pijet-Migon 2007 and Trzepacz 2007.

\section{THE PRESENT AND FORECAST SPATIAL PATTERN OF MARKET CATCHMENT AREAS}

In 2009, Poland had eleven civil airports servicing regular flights. Their offers differ markedly, as of course does the actual intensity of traffic in terms of aircraft and passengers. Nevertheless, disparities in intensity of traffic between airports have been decreasing steadily since 2004 , owing to deregulation and the appearance of low-cost carriers. 2008 was in fact the first ever year in which the regional airports taken together catered for more passengers than did the capital city's Warsaw-Okęcie Airport (Fig. 1).

The geographical distribution of the country's eleven airports is not an even one in respect to either demographic and economic potential or land-transport infrastructure (including roads). Consequently, the true reach of the respective catchment areas is very differentiated (Fig. 2A). While they form a relatively uniform pattern in western Poland, the pattern is markedly distorted in the east and partly also the north, where the networks of civil airports and of modern roads are much less dense. The result is a very extensive market catchment area for Warsaw-Okęcie airport, which encompasses, not only Mazowsze (Mazowieckie voivodship) and the whole of Podlasie (Podlaskie voivodship), but also considerable parts of the voivodships of Warmia-Mazury and Lublin (Warmińsko-Mazurskic and Lubelskie voivodships). Also relatively large are the catchment areas of the Gdańsk-Rębiechowo Airport (Pomorskie voivodship) plus 2/3 of Warmińsko-Mazurskie) and RzeszówJasionka Airport (large parts of Lubelskie and Świętokrzyskie voivodships). The existence of some rather smaller cities on the boundaries between catchment zones might be considered a premise upon which to establish airports in those very places. This is particularly true of Lublin and Kielce (the latter situated on the fringes of the catchment zones of as many as five airports!), as well as Opole. Such urban centres as Olsztyn and Koszalin are also situated close to the boundaries of catchment zones. At the same 

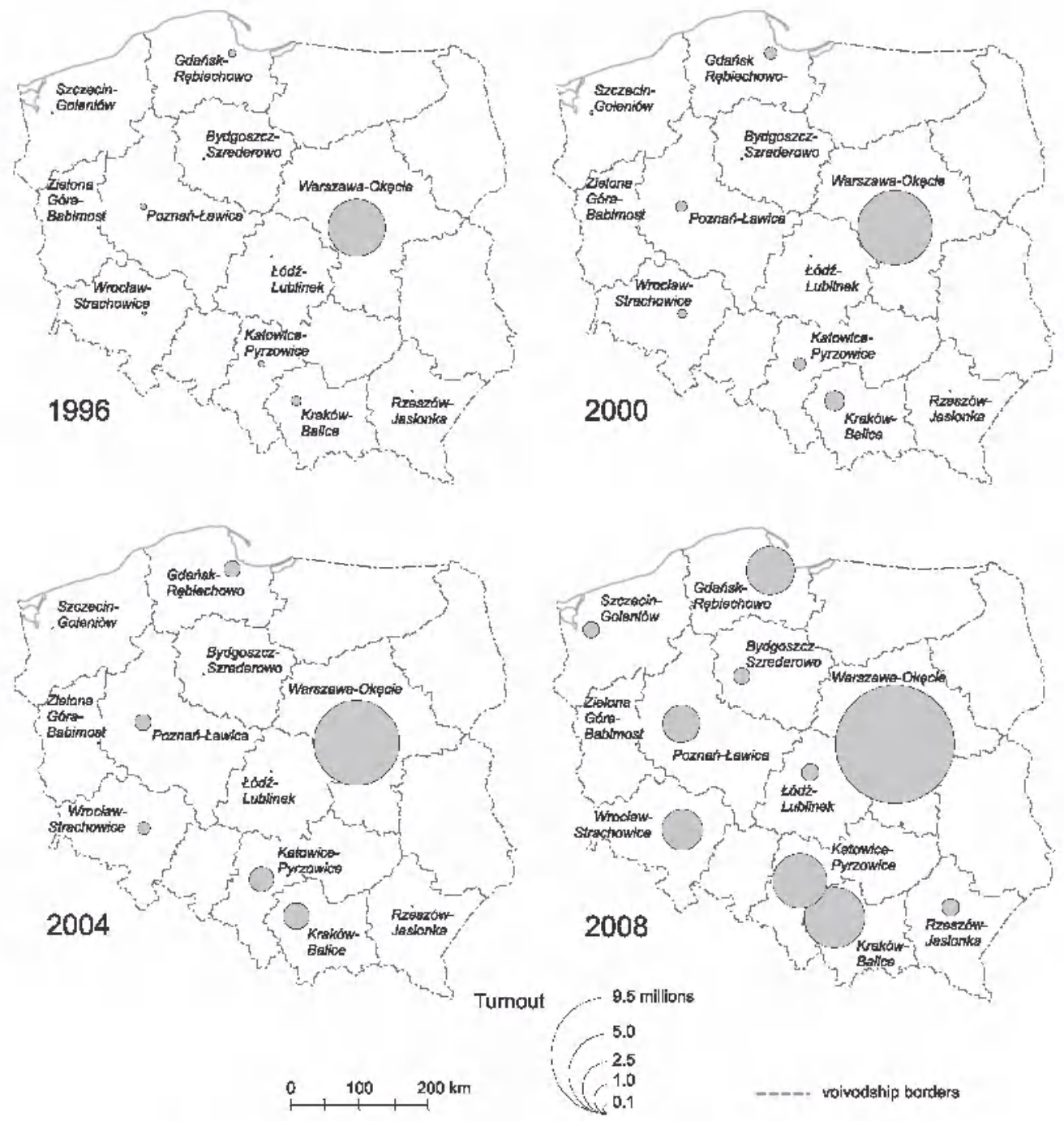

Figure 1. Development of passsenger air transport in Poland, 1990-2008.

time, an area of potential competition is becoming visible in the eastern part of the Upper Silesian conurbation, between KrakówBalice and Katowice-Pyrzowice Airports. Towns whose market can be the subject of competition between two or more airports in turn include Płock (Warsaw-Okęcie vs. Lódź-Lublinek), Tárnów (Krảków-Balice vs. Rzeszów-Jasionka), Gorzów Wielkopolski (Szczecin-Goleniów vs. Ziclona GóraBabimost), and Kàlisz (Poznań-Jasionká,
Wrocław-Strachowice and Łódź-Lublinek). In the cases of rivalry listed here, the winning side is likely to depend in practice upon the sequence with which road construction projects are carried out. Thus, for instance, an end to construction work on the segment of the S3 expressway from Szczecin to Gorzów Wielkopolski (as planned for 2010) should bring the latter within the market catchment zone of the airport in Goleniow. However, as the self-same road is further 

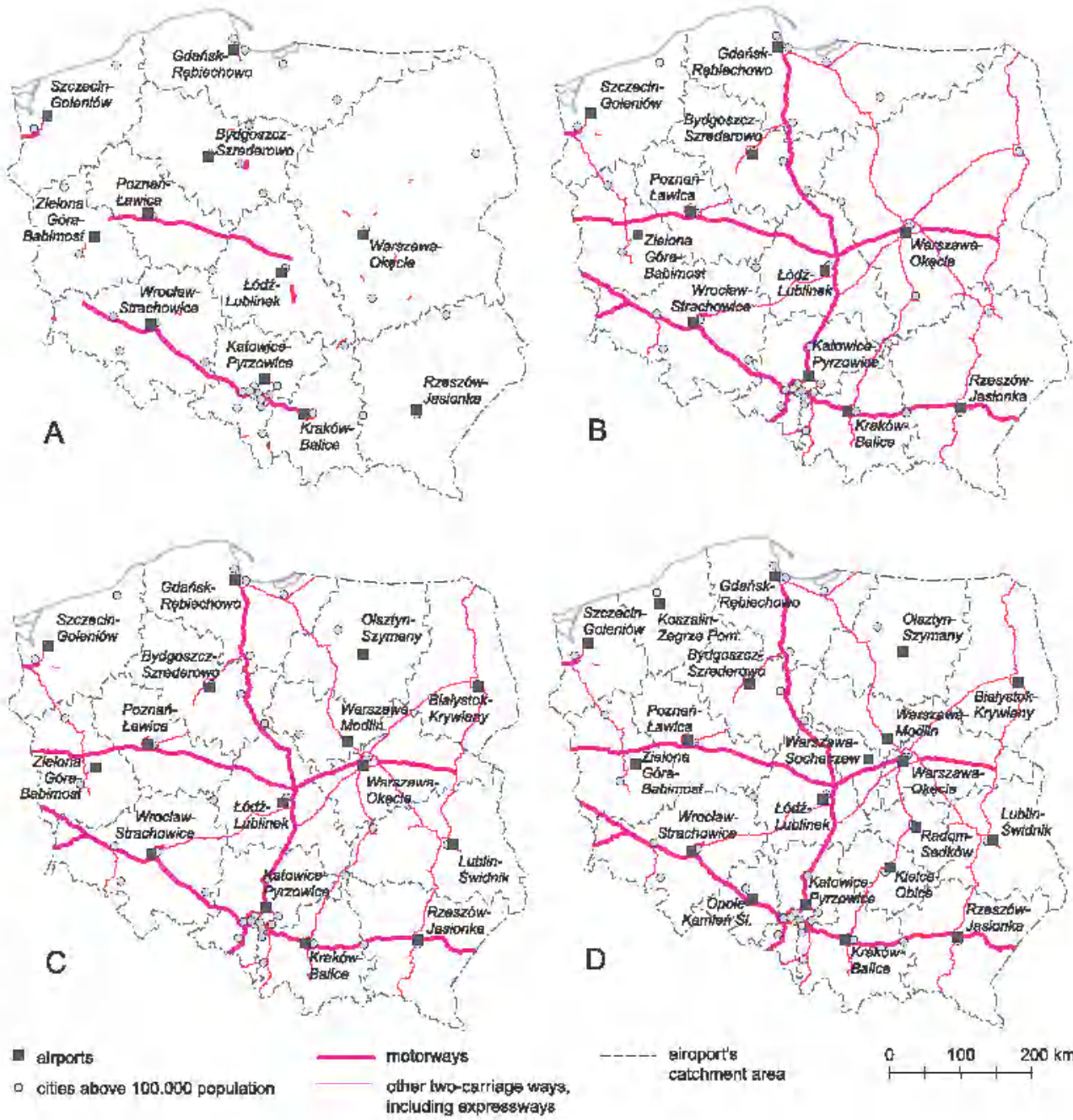

giraport's

catchment area

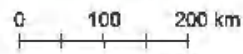

Figure 2. The current and the forecasted spatial reaches of the market catchment areas of Polish airports. Variants as described in the text.

extended towards Zielona Góra, the present spatial setting will be restored, competition for passengers from this city again flourishing between the airports of Goleniow and Babimost.

If we assume that no new airports will have come into operation as of 2013 (in line with Variant B, Fig. 2B), then changes in the reaches of market catchment areas will depend solely on improved accessibil- ity of facilities where road infrastructure is extended. Such changes are not likely to be spectacular, since there is relatively even coverage of Polish territory by planned ground infrastructure projects. Among the more significant envisaged transformations of the spatial setting we should mention:

- the northward extension of the market area of Rzeszów-Jasionka Airport, at the expense of Okęcie (beyond Lublin, up to the 
Puławy-Lubartów line), which ought to be associated with the planned construction of the S19 expressway;

- southward enlargement (in the direction of Toruń) of the market area of GdańskRębiechowo Airport, as a consequence of construction of the A1 motorway;

- northward spatial development of the market area of Katowice-Pyrzowice Airport beyond the boundary with the province (voivodship) of Łódź, also owing to the construction of the A1 motorway;

- a slight eastward shift in the boundary of the market area of Kraków-Balice Airport (motorway A4).

If four new facilities start functioning in the period considered (Variant C, Fig. 2C), then the spatial pattern to Poland's airport catchment areas will become significantly more even. Changes with respect to Variant $\mathrm{B}$, as described above, will affect eastern Poland only. The present-day catchment zone of Okęcie will be fragmented as significant parts of it will be taken over by all of the new airports (Białystok, Lublin, Szymany and Modlin). Likewise, there will be significant decreases in the catchment zones of Rębiechowo (to the advantage of Szymany) and Jasionka (to the advantage of Lublin), and a slight decrease for the catchment of Bydgoszez (to the advantage of Modlin). In the new circumstances the catchment area of Okęcie will encompass the majority of the agglomeration of Warsaw (except for its northern part), southern and eastern $\mathrm{Ma}$ zowsze (Mazowieckie voivodship), as well as the northern fringe of Lubelskie (Lublin) voivodship. Potential competition for the Warsaw market between Okęcie and Modlin is to be expected (of course under the assumption that the two offers will prove competitive rather than complementary). In the new division of market areas, Radom will be situated at a boundary of such areas.

If the development of the air transport market up to the year 2015 allows for the opening and economically justified activity of 5 further airports, then we can expect, again, an uneven spatial distribution of catchment zones of the 20 potentially functioning civil airports. This is especially true of central and southern Poland, in which new facilities with spatially limited catchment zones would appear (Sochaczew, Radom, Kielce and Opole). The airport in Sochaczew would cater to a small market area of the western fringe of the agglomeration of Warsaw, as well as the borderland of the provinces of Warsaw and Lódź. This area would appear at the expense of the catchments of Okęcie, Modlin and LódźLublinek. The catchment zone of RadomSadków would encompass the southern part of Mazowieckie voivodship, at the expense of Okęcie and Lublin. However, the reach of this new catchment zone would not include fragments of the metropolitan area of Warsaw, in view of the existence of the S7 expressway and the location of Okęcie to the south of Warsaw. The airport at KielceObice would take over fragments of as many as five market areas, determined in Variant C. At the same time, the airports of Radom and Kielce would have to compete among themselves for the market of Świętokrzyskie voivodship. The catchment zone of the potential Opole Airport would encompass an area approximating to Opolskie voivodship and would emerge at the expense of areas otherwise associated with Wroclaw-Strachowice and Katowice-Pyrzowice. Owing to the existence of the A4 motorway, this airport would become involved in the competitive struggle for passengers from the western part of the Upper Silesian conurbation (the vicinity of Gliwice). On the other hand, establishment of an airport in Koszalin would not in essence change the geographical pattern to the catchment areas, the new airport taking over parts of the market areas of Szczecin-Goleniów, Gđannsk-Rębiechowo (up to Słupsk) and Bydgoszcz.

In Variant D, the most spatially extensive catchment areas in Poland after 2015 would be those of Wroclaw-Strachowice, Szymany, Białystok and Rzeszów-Jasionka Airports. If the existence of twenty airports ultimately emerged as justified economically, it would be possible to indicate further potential airport facilities in the area of the Sudety Mts. 
(e.g. Jelenia Góra), in the Suwałki region, and in the Carpathian Mts.

\section{DEMOGRAPHIC AND ECONOMIC DEMAND IN CATCHMENT AREAS}

Currently, the largest absolute population (of potential passengers for airborne transport, Table 1) is that in the catchment zone of Warsaw-Okęcie Airport (7.7 million), followed by the zones around Pyrzowice (5.0 million) and Rzeszów-Jasionka (4.3 million). In the first and third cases these high numbers are partly due to the scarcity of airports in eastern Poland. In turn, the smallest market areas, populationwise, are those of Zielona Góra-Babimost (1.4 million), Szczecin-Goleniów (1.6 million) and Poznań-Lawica (2.1 million). The disparities become even greater when we apply the weighted demographic indicator (Table 3). Close to $24 \%$ of domestic demand falls upon Warsaw-Okęcic Airport, largely due to the concentration of the wealthier and better-educated population in the capital city region. The facilities of KatowicePyrzowice, Krakow-Balice and WroclawStrachowice each cater for some 10-12\% of the demand determined in this way. Hence, the weighted demand is consistently higher for the catchment areas surrounding the large poly-functional centres. A somewhat different spatial distribution, as well as more pronounced concentration appears in the case of economic demand. In terms of absolute numbers, the most businesses (Table 2) are again located in the catchment zone of Okęcie, as followed by Pyrzowice and Wroclaw-Strachowice. When we apply

Table 1. Populations within the market catchment areas of airports (in thousands).

Variants as described in the text.

\begin{tabular}{|c|c|c|c|c|}
\hline Airport & A & $\mathrm{B}$ & $\mathrm{C}$ & $\mathrm{D}$ \\
\hline Bialystok-Krywlany & - & - & 1,350 & 1,350 \\
\hline Bydgoszcz-Szrederowo & 2,568 & 2,306 & 2,204 & 2,069 \\
\hline Gdańsk-Rębiechowo & 3,058 & 3,444 & 2,672 & 2,470 \\
\hline Katowice-Pyrzowice & 5,024 & 4,547 & 4,547 & 3,987 \\
\hline Kielce-Obice & - & - & - & 992 \\
\hline Kószálin-Zegrzze Pomorskiè & - & - & - & 787 \\
\hline Kraków-Balice & 3,392 & 3,826 & 3,826 & 3,731 \\
\hline Lublin-Świdnik & - & - & 2,705 & 1,804 \\
\hline Lódź-Lublinek & 3,054 & 3,077 & 3,003 & 2,491 \\
\hline Olsztyn-Szymany & - & - & 1,301 & 1,301 \\
\hline Opole-Kamień Śląski & - & - & - & 957 \\
\hline Poznań-Ławica & 2,132 & 2,016 & 2,016 & 2,013 \\
\hline Rảom-Sảdków & - & - & - & 825 \\
\hline Rzeszów-Jasionka & 4,321 & 4,504 & 2,843 & 2,696 \\
\hline Szczecin-Goleniów & 1,618 & 1,585 & 1,585 & 1,138 \\
\hline Warsaw-Modlin & - & - & 973 & 753 \\
\hline Warsaw-Okęcie & 7,773 & 7,506 & 3,787 & 3,405 \\
\hline Warsaw-Sochaczew & - & - & - & 580 \\
\hline Wroclaw-Străchowice & 3,810 & 3,891 & 3,891 & 3,356 \\
\hline Zielona Góra-Babimost & 1,362 & 1,411 & 1,411 & 1,411 \\
\hline
\end{tabular}

Source: own elaboration 
Table 2. Numbers of enterprises (registered economic entities) within the market catchment areas of airports (in thousands). Variants as described in the text.

\begin{tabular}{lrrrr}
\hline Airport & \multicolumn{1}{c}{ A } & \multicolumn{1}{c}{ B } & C & D \\
\hline Bialystok-Krywlany & - & - & 102 & 102 \\
Bydgoszcz-Szrederowo & 231 & 214 & 207 & 192 \\
Gdańsk-Rębiechowo & 301 & 331 & 266 & 243 \\
Katowice-Pyrzowice & 454 & 401 & 401 & 360 \\
Kielce-Obice & - & - & - & 85 \\
Koszalin-Zegrze Pomorskie & - & - & - & 95 \\
Kraków-Balice & 317 & 355 & 355 & 347 \\
Lublin-Świdnik & - & - & 202 & 127 \\
Lódź-Lublinek & 280 & 292 & 286 & 237 \\
Olsztyn-Szymany & - & - & 101 & 101 \\
Opole-Kamień Śląski & - & - & - & 85 \\
Poznań-Ławica & 245 & 233 & 233 & 232 \\
Radom-Sadków & - & - & - & 68 \\
Rzeszów-Jasionka & 300 & 314 & 192 & 182 \\
Szczecin-Goleniów & 202 & 199 & 199 & 141 \\
Warsaw-Modlin & - & - & 80 & 61 \\
Warsaw-Okęcie & 815 & 795 & 510 & 476 \\
Warsaw-Sochaczew & - & - & - & 50 \\
Wroclaw-Strachowice & 399 & 405 & 405 & 351 \\
Zielona Góra-Babimost & 143 & 147 & 147 & 147 \\
\hline
\end{tabular}

Source: own elaboration

weighted demand (Table 4), we a observe strong concentration in the same centres as in the case of demographic demand (the airports of Warsaw, Katowice, Kraków and Wroclaw), with the roles of Okęcie and Strachowice being relatively somewhat greater, while those of Pyrzowice and Balice are somewhat more limited. Warsaw-Okęcie concentrates close to $29 \%$ of demand, this fact reflecting the strong concentration of businesses of the service sector and those with international connections.

Irrespective of the nature of the measure applied, the extension of road infrastructure up to the year 2015 will entail a distinct increase in demand, both demographic and economic, within the catchment areas of the airports of Gdańsk-Rębiechowo and Kraków-Balice, and, to a lesser degree, also Rzeszów-Jasionka (only demographic de- mand). Simultaneously, both types of demand will clearly decrease for Katowice-Pyrzowice, and also, though to a lesser degree, for Warsaw-Okęcie and Poznań-Ławica. Positions of the remaining airports will not undergo more significant changes.

The simultaneous bringing into use of the airports in Lublin, Białystok, Szymany and Modlin will cause an abrupt drop in both kinds of demand within the catchment area of Okęcie. However, this is primarily true of the absolute demographic demand (which will drop by half in comparison with the current situation, down to the level of 3.8 million people within the area). The accompanying decrease in the number of businesses catered to will be somewhat smaller (Table 2), since the concentration of businesses in the capital is greater than that of population. The respective losses are even smaller when 
Table 3. Weighted demographic demand within the market catchment areas of the airports (Poland $=100)$. Variants as described in the text.

\begin{tabular}{lrrrr}
\hline Airport & \multicolumn{1}{c}{ A } & \multicolumn{2}{c}{ B } & \multicolumn{2}{c}{ C } \\
\hline Bialystok-Krywlany & - & - & 2.9 & 2.9 \\
Bydgoszcz-Szrederowo & 5.3 & 4.9 & 4.7 & 4.5 \\
Gdańsk-Rębiechowo & 8.2 & 9.3 & 7.1 & 6.6 \\
Katowice-Pyrzowice & 11.9 & 10.6 & 10.6 & 9.6 \\
Kielce-Obice & - & - & - & 1.9 \\
Koszalin-Zegrze Pomorskie & - & - & - & 2.2 \\
Kraków-Balice & 11.5 & 12.5 & 12.5 & 12.3 \\
Lublin-Świdnik & - & - & 5.4 & 3.7 \\
Lódź-Lublinek & 6.6 & 6.9 & 6.7 & 5.6 \\
Olsztyn-Szymany & - & - & 3.0 & 3.0 \\
Opole-Kamień Śląski & - & - & - & 2.0 \\
Poznań--awica & 5.7 & 5.5 & 5.5 & 5.4 \\
Radom-Sadków & - & - & - & 1.5 \\
Rzeszów-Jasionka & 8.3 & 8.6 & 5.1 & 4.9 \\
Szczecin-Goleniów & 5.3 & 5.2 & 5.2 & 3.7 \\
Warsaw-Modlin & - & - & 1.9 & 1.4 \\
Warsaw-Okęcie & 23.6 & 22.8 & 15.5 & 14.8 \\
Warsaw-Sochaczew & - & - & - & 1.1 \\
Wroclaw-Strachowice & 10.3 & 10.4 & 10.4 & 9.2 \\
Zielona Góra-Babimost & 3.4 & 3.5 & 3.5 & 3.5 \\
\hline
\end{tabular}

Source: own elaboration

weighted demands a re considered. The share accounted for by Okęcie in terms of total demographic demand would decrease from the present $23.6 \%$ to $15.5 \%$, while the share of economic demand would fall from $28.7 \%$ to just under $23 \%$. It can thus be conceded that, owing to the concentration in the capital city of businesses with strong international ties, and of a better-earning and better-educated population, the establishment of the new airports (including Modlin) is not likely to bring about significant fluctuations in the functioning of Warsaw's Okęcie airport. There would, on the other hand, be a clearly perceptible decrease in demand in the catchment areas of Rzeszów-Jasionka and Gdańsk-Rębiechowo. Among the four new facilities, the one forecast to have the highest demand, both demographic and economic, is Lublin, while Modlin is expected to manifest the lowest level of demand. However, the role of Modlin is certain to grow, in view of the relative inaccessibility of Okęcie from the northern part of the capital-city agglomeration in conditions of road congestion. It is also important to note the envisaged specialisation of Modlin Airport in specific kinds of connections and market segments (chartered flights, low-cost airlines, cargo and night flights).

The establishment of as many as nine new facilities in the years up to 2015 will impact upon the figures for the most important airports to only a limited degree. In particular, these airports will not experience much effect beyond that arising out of the situation with four new facilities being opened. Despite the assumed establishment of the airport at Sochaczew, the demand indicators for Warsạw-Okęcie are not expected to 
Table 4. Weighted economic demand within the market catchment areas of the airports (Poland $=100)$. Variants as described in the text.

\begin{tabular}{lrrrr}
\hline Airport & \multicolumn{1}{c}{ A } & \multicolumn{1}{c}{ B } & \multicolumn{1}{c}{ C } \\
\hline Bialystok-Krywlany & - & - & 2.0 & 2.0 \\
Bydgoszcz-Szrederowo & 4.4 & 4.1 & 4.0 & 3.8 \\
Gdańsk-Rębiechowo & 8.0 & 8.9 & 7.1 & 6.7 \\
Katowice-Pyrzowice & 10.3 & 9.0 & 9.0 & 8.0 \\
Kielce-Obice & - & - & - & 1.3 \\
Koszalin-Zegrze Pomorskie & - & - & - & 2.2 \\
Kraków-Balice & 10.4 & 11.4 & 11.4 & 11.3 \\
Lublin-Świdnik & - & - & 3.6 & 2.5 \\
Łódź-Lublinek & 5.4 & 5.6 & 5.5 & 4.7 \\
Olsztyn-Szymany & - & - & 2.4 & 2.4 \\
Opole-Kamień Śląski & - & - & - & 2.0 \\
Poznań-Lawica & 6.5 & 6.4 & 6.4 & 6.4 \\
Radom-Sadków & - & - & - & 1.0 \\
Rzeszów-Jasionka & 5.4 & 5.6 & 3.3 & 3.1 \\
Szczecin-Goleniów & 6.0 & 5.9 & 5.9 & 4.4 \\
Warsaw-Modlin & - & - & 1.5 & 1.2 \\
Warsaw-Okęcie & 28.7 & 28.0 & 22.8 & 22.2 \\
Warsaw-Sochaczew & - & - & - & 0.9 \\
Wroclaww-Stráchowice & 10.9 & 11.0 & 11.0 & 9.9 \\
Zielona Góra-Babimost & 3.9 & 4.0 & 4.0 & 4.0 \\
\hline
\end{tabular}

Source: own elaboration

undergo more major change. There will be further decreases in figures calculated for Pyrzowice, as well as for Strachowice and Lódź-Lublinek, and, to a lesser degree Szczecin-Goleniów. From among the airports whose establishment as new facilities was assumed in Variant C, the one losing out markedly with the opening of additional airports is Lublin. Losses incurred by Lublin, Okęcie and Łódź are to a large extent the effect of the potential opening of airports in Kielce and Radom. From among the potentially established five new airports the highest demand would fall upon the catchment areas of Koszalin and Opole, though Kielce would also be concerned from the point of view of demographic demand. The smallest expected decreases in demand are envisaged for Radom and Sochaczew. However, the situation of the latter is similar to that of the previously mentioned Modlin, and the actual air transport market for Sochaczew may turn out to be larger. It is worth noting that, if a single airport were to be established in place of Kielce-Obica and RadomSadkow, its catchment area would feature relatively high values for indicators of both demographic and economic demand.

Assuming twenty functioning civil airports in Poland by 2015, as well as an end brought to all planned road-construction projects, Warsaw-Okęcie will remain the airport catering to the catchment area with the highest demographic demand (close to $15 \%$ of the total national weighted demand) and economic demand (more than $22 \%$ of the weighted demand). Second place would then be taken by Krakow-Balice (with respective values of 12.3 and $11.3 \%$ ), followed by Wroclaw-Strachowice and $\mathrm{Ka}$ - 
towice-Pyrzyce. Relatively lower, though stable, would be the position of the airport of Poznan-Ławica.

The currently functioning airports will be characterised by various sensitivities when it comes to the appearance of competing facilities. These will above all be dependent on the true market potential of the very urban centre (seat of voivodship) that a given airport is adjacent to. Stability with regard to economic demand is first and foremost guaranteed by a strong position of the services sector, as well as poly-functionality and international connections of the economy, and, with regard to demographic demand-by better education and higher incomes of the inhabitants. In both cases some role is also played by the concentration of the international, inward tourist traffic. The facilities that are resilient to the new developments are, certainly, Warsaw-Okęcie (despite the demand decrease in absolute terms), as well as Krakow-Balice, Wroclaw-Strachowice and Poznan-Lawica. In turn, to be mentioned as dependent upon the geographical reach of their respective market catchment areas are the facilities in Pyrzowice, Łodz-Łublinek and Gdansk-Rębiechowo.

\section{CONCENTRATION OF DEMAND WITHIN THE 60-MINUTE TRAVEL ZONE FROM THE AIRPORT}

The level of demand for air transport is also determined by an airport's accessibility on the local scale, as expressed by reference to the concentration of population and businesses within the nominally defined zone of a 60 -minute driving time (Table 5). This indicator depends strongly upon the state of development of the road infrastructure in the vicinity of the given airport. According to the current data (as of 2009) the greatest number of potential passengers inhabits the zone of 60 -minute travel to the airport of Warsaw-Okęcie (3.1 million), followed by Katowice-Pyrzowice and Krakow-Balice (more than 2 million each), while the lowest number is in the neighbourhood of the airports in Zielona Góra, Rzeszów and Szczecin. Development of road infrastructure within the framework of projects to have been completed by 2015 will result in a distinct increase in the demographic potential within the 60-minute travel zones for the airports at Katowice-Pyrzowice (from 2.4 to 3.9 million people), Kraków-Balice (from 2.3 to 3.1 million) and Rzeszów-Jasionka. The expansion of the zone around WarsawOkęcie will be much more moderate (with a 300,000-person increase only). Eikewise, the number of inhabitants within the isochrone of 60 minutes around the airports of Poznań and Łódź will not increase significantly at all. This all serves to confirm the more general proposition that the primary beneficiaries of the current programme of motorway and expressway construction in Poland will be southern, rather than central, regions. One should add to that the convenient location of the airports in Balice and Pyrzowice with respect to the envisaged road network (immediate proximity of existing and/or constructed motorways).

Among the airports whose establishment is planned, the highest concentration of demographic potential within the 60 minute travel zone will undoubtedly be manifested by Modlin (3.3 million people) and Sochaczew (2.6 million). Where planned airports not related to the agglomeration of Warsaw are concerned, the highest figures are for Radom-Sadków, Opole-Kamień Śląski and Kielce-Obice (roughly one million persons each). The concentration of businesses within the 60 -minute travel zones is even greater for the three most important airports (Okęcie, Balice and Pyrzowice). From among the potential new facilities the greatest direct economic hinterland in the form of functioning businesses will again characterise Modlin, Sochaczew, Radom, Kielce and Opole, as well as Łublin.

Earlier studies on accessibility of the existing and planned network of civil airports with regular flights (Komornicki and Śleszyński 2009b) demonstrate that $43 \%$ of Poland's inhabitants live currently within the isochrone of 60 -minute road travel from 
Table 5. Values for absolute and weighted demand indicators within the isochrone of 60 minutes in 2008 and 2013 (in thousands, or for Poland $=100$ ). Indicator notation is as given in the text.

\begin{tabular}{|c|c|c|c|c|c|c|c|c|}
\hline \multirow[b]{3}{*}{ Airport } & \multicolumn{2}{|l|}{$P_{P i t \mathrm{p} ;}$} & \multicolumn{2}{|l|}{$P_{3 \mid 1 !}$} & \multicolumn{2}{|l|}{$P_{S \%}$} & \multicolumn{2}{|l|}{$\mathrm{P}_{\mathrm{Bi} \mathrm{E} !}$} \\
\hline & 2008 & 2013 & 2008 & 2013 & 2008 & 2013 & 2008 & 2013 \\
\hline & \multicolumn{4}{|l|}{ thous. } & \multicolumn{4}{|c|}{ Poland $=100$} \\
\hline Bialystok-Krywlany & - & 608 & - & 48 & - & 1.7 & - & 1.3 \\
\hline Bydgoszcz-Szrederowo & 1,070 & 1,119 & 109 & 112 & 5.8 & 3.1 & 4.3 & 2.3 \\
\hline Gdańsk-Rębiechowo & 1,384 & 1,720 & 155 & 182 & 8.1 & 5.1 & 7.5 & 4.7 \\
\hline Katowice-Pyrzowice & 2,442 & 3,875 & 230 & 352 & 12.8 & 10.4 & 9.6 & 8.0 \\
\hline Kielce-Obice & - & 990 & - & 92 & - & 2.7 & - & 1.7 \\
\hline Koszalin-Zegrze Pomorskie & - & 317 & - & 38 & - & 0.9 & - & 0.7 \\
\hline Kraków-Balice & 2,343 & 3,053 & 261 & 316 & 13.8 & 9.0 & 17.1 & 10.5 \\
\hline Lublin-Świdnik & & 1,071 & & 82 & & 2.9 & & 2.0 \\
\hline Lódź-Lublinek & 1,678 & 1,935 & 177 & 198 & 9.2 & 5.5 & 6.9 & 4.1 \\
\hline Olsztyn-Szymany & - & 501 & - & 42 & - & 1.3 & - & 1.1 \\
\hline Opole-Kamień Śląski & - & 988 & - & 92 & - & 2.7 & - & 2.0 \\
\hline Poznań-Ławica & 1,396 & 1,451 & 186 & 192 & 8.5 & 4.6 & 8.2 & 4.5 \\
\hline Radom-Sadków & - & 1,041 & - & 95 & - & 2.8 & - & 1.7 \\
\hline Rzeszów-Jasionka & 695 & 1,603 & 50 & 110 & 3.4 & 4.0 & 2.1 & 2.3 \\
\hline Szczecin-Goleniów & 847 & 847 & 113 & 113 & 5.1 & 2.7 & 5.2 & 2.8 \\
\hline Warsaw-Modlin & - & 3,290 & - & 484 & - & 11.8 & - & 15.3 \\
\hline Warsaw-Okęcie & 3,054 & 3,387 & 471 & 494 & 21.5 & 12.1 & 27.9 & 15.5 \\
\hline Warsaw-Sochaczew & - & 2,562 & - & 383 & - & 9.3 & - & 12.4 \\
\hline Wroclaw-Strachowice & 1,416 & 1,631 & 170 & 188 & 8.5 & 5.0 & 8.5 & 4.9 \\
\hline Zièlona Góra-Bábimost & 672 & 904 & 69 & 96 & 3.4 & 2.4 & 2.7 & 2.1 \\
\hline
\end{tabular}

Source: own elaboration

the nearest airport, while $65 \%$ live within the 90-minute isochrone. The development of road infrastructure (leaving aside the establishment of any new airports) should raise values to 52 and $78 \%$ respectively by 2013 .

\section{DISCUSSION AND SUMMARY}

The analyses presented here allow for an assessment of the influence exerted by the development of Poland's road network on the characteristics of airport catchment areas. It must be stated that the programmes being implemented currently (the Government Programme of Motorway and Expressway Construction, as well as Operational
Programmes supported by funds from the European Union, above all including the Infrastructure and Environment $\mathrm{OP}$ ) will make a major contribution in the years up to 2013/2015 where improved accessibility to Polish airports is concerned, even if no new airports are opened in this period. Over this time perspective, there will be a significant increase in population size and numbers of businesses located relatively close to the nearest airport. At the same time, the influence of road construction projects on the accessibility of airports will be subject to regional differentiation, with a preference being shown for southern Poland. It is further shown that the development of some facilities depends more on the market concentrat- 
ed in the neighbouring large city, while others will have to compete to a greater extent for customers from peripheral areas. This is reflected in the respective need for road construction projects. In the former case what is of greatest importance is a good connection with the centre of the large city (in terms of road and also rail transport), while in the latter case it is good accessibility from the hinterland as broadly conceived that matters most. The airports for which the road infrastructure inside the agglomeration is of key importance are Warsaw-Okęcie, KrakówBalice, Wrocław-Strachowice and PoznańLawica. Examples of the latter type of airports are provided by Katowice-Pyrzowice, Lódź-Lublinek and Gdańsk-Rębiechowo. The situation is similar with the airports catering for smaller centres (like Rzeszów, Bydgoszcz and Szczecin).

The success of the new airports in the regions of Warsaw and Kraków, as well as the Upper Silesian conurbation, depends very significantly upon road network development. This concerns in particular such airports as Modlin, Sochaczew and Kamień Sląski, whose convenient connections with Warsaw and the cities of the conurbation respectively, will be decisive for the appropriate expansion of catchment areas, within which the cores of the respective centres are to be included. On the other hand, the increasing congestion in downtown areas, and the lack of smooth circumventing traffic in large cities and conurbations, becomes the justification for the construction of second airports, situated geographically on the other side of the respective agglomeration. In line with the study carried out under the Strategy for the Development of Civil Aviation in Mazowsze (Komornicki and Śleszyński $2009 \mathrm{~b}$ ), after the S7 expressway is put into use along its Warsaw-Gdańsk section, the travel times to the planned airport in Modlin in conditions of road congestion will be comparable for the vicinity of Olsztynek (Warmińsko-Mãurskie voivodship) and Ursynow district in the south of Warsaw.

However, extension of the road network ought not to be perceived uniquely as stimu- lating the development of regional air transport markets. In some cases the planning of new airports takes place in abstraction from ground infrastructure projects. Bad connections by road transport may happen to be the justification for the establishment of airborne transport, for instance to secure fast travel from regional and subregional centres to the capital. The analysis of accessibility and the pattern to market catchment areas allows for a critical insight into these kinds of designs. Construction of motorways and expressways will improve the accessibility of the already-existing network of airports and may lower the future profitability of planned facilities. This applies, in particular, to the S7 expressway from Warsaw to Kraków, along which two civil airports are planned: in Radom-Sadków and KielceObice. Their catchment areas will undergo significant shrinking with improved accessibility of Okęcie (situated close to route S7), and of Balice. In addition, the two new facilities will compete themselves. A similar situation may arise in the case of the planned Koszalin-Zegrze Pomorskie Airport, once the S6 expressway is constructed (after 2015). The S3 might be perceived as a threat to the economic viability of the airport in Babimost. Likewise, the effect of termination of the A2 motorway, along its Stryków-Konotopa section, with simultaneous completion of the southern bypass of Warsaw, may turn out to be of ambiguous significance for the development of Łódź Airport.

While the present report is limited to Polish territory, it is obvious that foreign airports located close to the border do also compete for Polish passengers. This is above all true of Berlin airport (in fact two airports until 2010), as well as of the airports in Dresden, Prague and Ostrava. At the same time, Warsaw-Okęcie Airport remains the closest facility with an extensive network of international connections for western Belarus. The development of road infrastructure can be expected to improve the accessibility of foreign airports and will thus strengthen their competitive position on the territory 
of Poland. This will be the effect of the finalisation of the A18 motorway and of the western segment of the $A 2$, resulting in a significant shortening of car travel times to Berlin from Poznań and Wroclaw. In the latter case especially the time of travel to Berlin will become much shorter than that to Warsaw (especially during the several years in which the $A 18$ is already operating, while the S8 expressway between Wroclaw and Lódź is not yet ready). Simultaneously, the western segment of the $A 4$ and the southern section of the A1 will respectively improve the accessibility of the airports in Dresden and Ostrava. It is also highly probable that construction of the S19 road to the south of Rzeszów may extend the true market catchment area of the airport at Jasionka to include part of north-eastern Slovakia.

\section{REFERENCES}

Adrangi, B., Chatrath, A. and Raffiee, K. (2001), The demand for US air transport service: a chaos and nonlinearity investigation. Transportation Research Part E: Logistics and Transportation Review, 37, 337-353.

Bieger, T., Wittmer, A. and Laesser, Ch. (2007), What is driving the continued growth in demand for air travel? Customer value of air transport. Journal of Air Transport Management, 13, 31-36.

Blake, A. and Sinclair, M.T. (2003), Tourism crisis management - US response to September 11. Annals of Tourism Research, 30, 813-832.

Concepción, R., Raquel E. and Martín J.C. (2007), Competition of high-speed train with air transport: The case of Madrid-Barcelona. Joumal of Air Transport Management, 13, 277-284.

Czyczuła W., Filarska A. and Gertz J. (2005), Rozwój transportu lotniczego w Polsce w zwiazku $z$ ekspansja tanich przewozników [Development of air transport in Poland in connection with the expansion of cheap cartiers], (in Polish), Przeglad Komunikacyjny, 9.

Encaoua, D., Moreaux, M. and Perrot, A. (1996), Compatibility and competition in airlines Demand side network effects, International Journal of Industrial Organization, 14: 701-726.
Espon 1.1.1 Final Report (2005), ESPON, Luxemburg.

Garriga, J.C. (2006), Airport accessibility, a territorial approach, Strair, Barcelona.

Graham, B. (1998), Liberalization, regional economic development and the geography of demand for air transport in the European Union. Joumal of Transport Geography, 6: 87-104.

Grzelakowski, A.S. (2005), Transport lotniczy wobec wyzwań regionalnych (WE) i globalnych. Problemy regulacyjne i dostosowaweze [Air transport facing the regional (WE) and the global challenges. Regulative and adaptive problems], (in Polish), Przeglad Komunikacyjny, 9.

Huff, D.L. (1964), Defining and estimating a trading area, Journal of Marketing, 28: 34-38.

Janic, M. (1997), Comparison of the quality of rail and air networks in West, Central and Eastern Europe, Transport Policy, 4: 85-93.

Kitowski, J. (1999), Port Lotniczy w Rzeszowie strategicznym czynnikiem rozwoju południowej częśsi Ściany Wschodniej [Airport in Rzeszow as a strategic factor of development of south part of the so-called 'Eastern Wall' (i.e. east of Poland)], Prace Komisji Geografii Komunikacji PTG, 5: 77-87.

Komornicki, T., Sleszyński, P. (2009a), Prognozowana dostępność przestrzenna i ksztaltowanie się popytu na usługi lotnicze w latach 2008-2015 [Projected spatial accessibility of airports and shaping of demographic and economic demand in the years 2008-2015], Prace Komisji Geografii Komunikacji PTG, 16: 115-130.

Komornicki T., Śleszyński, P. (ed.) (2009b), Studia nad lokalizacją regionalnych portów lotniczych na Mazowszu [Location studies for regional airports in Mazovia], Prace Geograficzne, 220, Instytut Geografii i Przestrzennego Zagospodarowania (IGiPZ), PAN, Warszawa.

Kopeć, K. (2004), Port lotniczy w Gdańsku-jego funkcjonowanie i perspektywy rozwoju [Airport in Gdańsk-its functioning and development perspectives], Prace Komisji Geografii Komunikacji PTG, 10: 357-366.

Lai, S.L. and Lu, W-L. (2005), Impact analysis of September 11 on air travel demand in the USA. Joumal of Air Transport Management, 11: $455-458$. 
Pantazis, N. and Liefner I. (2006), The impact of low-cost carriers on catchment areas of established international airports: The case of Hanover Airport, Germany. Joumal ofiTransport Geography, 14: 265-272.

Park, Y: and Ha, H.-K. (2006), Analysis of the impact of high-speed railroad service on air transport demand, Transportation Research Part E: Logistics and Transportation Review, 42: 95-104.

Pels, E., Nijkamp, P. and Rietveld, P. (2000), Airport and airline competition for passengers departing from a large metropolitan area, Journal of Urban Economics, 48, 1: 29-45.

Pijet-Migoń, E. (2007), Lotnicze przewozy pasażerskie w Polsce po akcesji do Unii Europejskiej-wymiar przestrzenny [Passenger air traffic in Poland after accession to the European Union-a spatial dimension], Prace Komisji Geografii Komunikacji PTG, 14: 107-122.

Reilly, W.J. (1931), The law of retail gravitation. Putnam, New York.
Trzepacz, P. (2007), Kierunki i uwarunkowania rozwoju sieci portów lotniczych Polski [Directions and conditions of airport network development in Poland], Prace Komisji Geografii Komunikacji PTG, 14: 123-147.

Węcławowicz, G., Bański, J., Degórski, M., Komornicki, T., Korcelli, P., Śleszyński, P., (2006), Przestrzenne zagospodarowanie Polski na początku XXI wieku [Spatial organization of Poland at the beginnig of the $21^{\text {st }}$ century], Monografie, 6, Instytut Geografii i Przestrzennego Zagospodarowania (IGiPZ) PAN, Warszawa.

Paper first received: May 2011

In final form: November 2011 
http://rcin.org.pl 